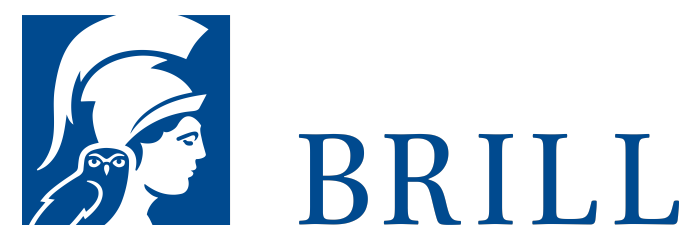

\title{
Absolute Architekturbeginner
}

Schriften 2004-2014

Author: Stephan Trüby

Entgegen den Bekundungen aller Reinheits- und KlarheitsPhantasmen, die das architektonische Denken zyklisch wie Sagrotan-Schwaden durchziehen, ist die Architektur vor allem ein Mischprodukt: ein manchmal bewusster, meist aber unbewusster Projektionsakt von spezifischen Designelementen auf andere spezifische Designelemente.

Dabei entsteht Neuheit, entstehen Projekte und Gebäude, die ihren Hybrid-Charakter kaum verleugnen können und von einer noch zu begründenden Transmissionskunde, einer Wissenschaft der Fusionen und Übernahmen zu analysieren sind. Denn was sollte kulturelle und damit auch architektonische Evolution sein, wenn nicht vor allem ein ewiges Hin und Her meta-ökonomischer Mergers \& Acquisitions-Geschäfte? In Absolute Architekturbeginner entfaltet Stephan Trüby ein aus architektonischer Perspektive betrachtetes kulturtheoretisches Panorama, das ein Denken in Kontinuitäten mit einer Aufmerksamkeit für relative Nullpunkte verbindet.

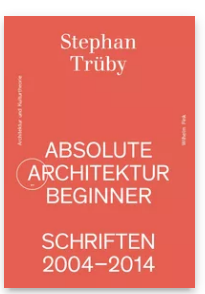

Pages: 263

Seiten, $234 \mathrm{~s} / \mathrm{w}$

Abb.

Language:

German

Subjects:

Architecture, Art

History

Publisher: Brill |

Fink

Series:

Schriftenreihe

für Architektur

und

Kulturtheorie,

Volume: 1

E-Book (PDF)

Released online:

29Jan 2020

ISBN: 978-3-

8467-6o36-9

List price

Paperback

Publication date:

10 Mar 2017

ISBN: 978-3-

7705-6о36-3

List price 
For more information see brill.com

Order information: Order online at brill.com +44330 333 0049 | customerservices@brill.com Submission information: brill.com/authors

Titles published by Brill | Fink, Brill | mentis or Brill | Schöningh: +49(o)715413279216| brill@brocom.de 